ist auch an Fad. 4 um 5.8 beobachtet, dieser Faden aler ausgeschlossen, weil Fad. 5 als genauer bezeichnet ist. Die Zeitfolge lehrt also, dass statt der Minute ${ }^{\text {m1 }}$ vielmehr $1^{\text {in }}$ zu suppliren ist, wodurch es nöthig wird, auch die AR. der beiden folgenden Sterne $u m I^{m}$ zu vermehren. Jie Minute I bei Nr. Io7, die der Druck hat, steht nicht in Original.

Nr. $\quad 24=$ A. Z. $269 \cdot 39$. Es ist jedenfalls Fad. 5 statt 3 zu lesen, wodurch ' 4 Isis 5 kleiner wird.

7301. Druckfehler bei Oeltzen.

$12646=$ A. Z. 383.4 . Es stand wirklich erst mit Herm Holden's Annahme übereinstimmend in Original $9^{\circ} 19^{\prime} 30^{\prime \prime} 1$, und die Zehner der Minuten sind dann mit Bleistift ausgestrichen. Stellt man die urspringliche Lesart wieder her, so wird auch $\mathrm{I}=\mathrm{I} 2^{\mathrm{h}_{\mathrm{L}}} 57^{\mathrm{in}} 53^{\mathrm{s}} \cdot 93$.

12906. Reductionsfehler von Oeltzen.

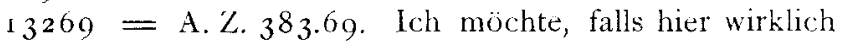
ein Fehler in AR. ist, eher glauben, dass die beobachteten Fäden nicht 5 und 6 waren, sondern 6 und 7 . In diesem Falle wüde $\mathrm{T}=$ $13^{\mathrm{h}} 48^{\mathrm{n}} 43^{\mathrm{s}} \cdot 39$ werden.

17586. Hiese Correction ist an sich nicht wahrscheinlich, da dann zu erwarten wäre, dass Argelander die Zeitminute nicht bei A. Z. 22 I.65, sondern schon bei Nr. 64 notirt hätte. Die Correctur wird gleichwohl richtig sein, da auch Lamont I 3 aus der Münchener Zone 405 sie fordert.

$19058=$ A. Z. 220.179 . Reductionsfehler in BB. II. Die Decl. muss iauten $23^{\circ} 28^{\prime} 42^{\prime \prime} 4$ und die mit dieser verbesserten Declination berechnete Durchgangszeit durch den Mittelfaden $\mathrm{T}={ }_{1} 8^{\mathrm{h}} 58^{\mathrm{m}}{ }^{\mathrm{m}}{ }^{\mathrm{s}} .98$.
Nr. $19370=$ A.Z.308.133. Es ist jedenfalls Faden 7 statt $5 \mathrm{zu}$ lesen, wodurch $\mathrm{T}$ um 2 I.og kleiner wird.

$2 \mathrm{I} 434=$ A.Z. 234.60 . Obwohl die Zeitminute $23^{\mathrm{m}}$ deutlich im Original steht, so wird sie doch $22^{\mathrm{m}}$ zu lesen sein (s. auch Cord.-Z. 32 , Nr. 85, 86).

$2 \mathrm{I} 436=$ A. Z. $234.6 \mathrm{I}$. Der Fehler ron $\mathrm{I}^{\mathrm{rn}}$ ist, wenn er beim vorigen stattfand, auch hier an sich sehr wahrscheinlich. In der Angabe des Mikroskops ist ein Abschreibefehler; nach Verbesserung aller dieser Fehler ist zu lesen:

A. Z. $234.6 \mathrm{I}: \mathrm{T}=2 \mathrm{1}^{\mathrm{h}} 22^{\mathrm{II}} 3^{5} \cdot 9^{8}, \mathrm{Mikr}=$ $4^{\circ} 34^{\prime}$ I $2^{\prime \prime} 9, \quad$ Decl $=23^{\circ} 52^{\prime} 2^{\prime \prime} 9$.

$22430=$ A.Z. 250.19 . Der nach der Zeitfolge der Beobachtungen sehr gut mögliche Fehler wird durch die suidliche Durchmusterung bestätigt, welche zugleich zeigt, dass derselbe schon bei $\mathrm{Nr}$. 8 stattgefunden hat, so dass alich Oe. 22420 $\mathrm{um}+\mathrm{I}^{\mathrm{m}} \mathrm{zu}$ corrigiren ist.

$23 \mathbf{2 3}=$ A. Z. 268.53. Reductionsfehler in BB. II. Das Fadenintervall $=20.08$ ist addirt statt subtrahirt, durch ein zweites, das erste versteckende Versehen aber die richtige Zeitminute beigeschrieben. $\mathrm{T}=23^{\mathrm{h}} 48^{\mathrm{m}} 27^{\mathrm{s}} .92$.

$23230=$ A.Z. $269 \cdot 34$, wo I $=23^{\mathrm{h}} 58^{\mathrm{m}} \mathrm{I} 7^{\mathrm{s}} \cdot 47$ zul lesen ist. Reductionsfehler.

23247 siehe Nr. I und $r 6$.

Bei den hier nicht besonders aufgefühten Nummern sind Argelander's Originale und Reductionen röllig zweifelfrei, auch kann ich, abgesehen von den Bemerkungen in A. N. $256 \mathrm{I}$, zu einer weiteren Kritik derselben nach eigenen Beobachtungen nichts beitragen.

Bonn I 884 Juli.

E. Schönfeld.

\title{
Corrections to the Windsor Right Ascensions of Comet 1883 II.
}

\author{
(Schreiben an den Herausgeber.)
}

I herewith forward to you a series of corrections to be applied to the conchided apparent right ascensions of Comet 1883 II, contained in my letter to you of the I $8^{\text {th }}$ Febr. last, and I trust they may reach you before a definitive determination of the Comet's orbit is attempted. As already intimated my differential comparisons of that Comet were made with a square bar-micrometer. The micrometer is similar to that described in the Introduction to Cooper's Catalogue of Ecliptic Stars with the addition of spider limes to represent the diagonal of the square. Previously to commencing the series of Comet observations the micrometer wats so adjusted that a star at an altitude of 40 degrees or upwirds would be bisected by one of the spider lines at the moment of its entering and quitting the field of the telescope. 'This adjustment was not altered during the whole series of observations and was repeatedly verified. It was found, however, by numerous comparisons of pairs of stars from Stone's Cape Catalogue whose difference of declination was considerable that this adjustment was not consistent with an exact orientation of the micrometer, and a constant was therefore deduced from these observations for the proper correction of the Comet's right ascensions already referred to. The following are the resulting corrections, those for the north polar distance being hardly sensible.

\begin{tabular}{|c|c|c|}
\hline I 884 & Winds. M. T & $\Delta a$ \\
\hline Jan. I 9 & $9^{h} 37^{m} 42^{s}$ & -0.14 \\
\hline 19 & 93742 & -0.02 \\
\hline 21 & $\begin{array}{lll}9 & 26 & 7\end{array}$ & -0.39 \\
\hline $2 \mathrm{I}$ & $93^{1} 39$ & -0.19 \\
\hline 22 & 934 & -0.48 \\
\hline 22 & $\begin{array}{lll}9 & 3 & 4\end{array}$ & -0.27 \\
\hline 23 & 922 I I & -0.53 \\
\hline
\end{tabular}




\begin{tabular}{|c|c|c|c|}
\hline \multicolumn{2}{|c|}{1884} & Winds. M. $T$. & $\Delta e$ \\
\hline Jan. & 23 & $9^{\mathrm{h}} 22^{\mathrm{ml}} I_{1} \mathrm{I}^{\mathrm{s}}$ & -0.32 \\
\hline & 24 & $\begin{array}{lll}8 & 51 & 49\end{array}$ & -0.54 \\
\hline & 24 & $\begin{array}{lll}8 & 5 \text { I } & 49\end{array}$ & --0.34 \\
\hline & 25 & $9 \quad 1435$ & -0.55 \\
\hline & 25 & $9 \quad$ I 435 & -0.34 \\
\hline & 27 & $\begin{array}{lll}8 & 50 & 59\end{array}$ & $-0.4^{8}$ \\
\hline & 27 & $8 \quad 50 \quad 59$ & -0.28 \\
\hline & 28 & $8 \quad 56 \quad 48$ & +0.60 \\
\hline & 28 & $\begin{array}{lll}86 & 48\end{array}$ & +0.58 \\
\hline Febr & 2 & 9389 & -0.57 \\
\hline
\end{tabular}

A singular fatality seems to have attended many of the reductions in connexion with this Comet. I observe that in Nr. 2583 of the Astr. Nachr. Dr. Kreutz has made use of my differential observations in Nr. 84 of the $\gg$ Observatory « for testing the orbit derived by Dr. Oppenheim from certain positions obtained at Melbourne. It appears to me, however, that his reductions of the stars from the mean to the apparent places are, with the exception of the first, erroneus. In order to avoid both systematic and accidental errors my own reductions were effected by two different methods, namely, by the method described in the Introduction to Stone's Cape Catalogue and by the use of the quantities on page 303 of the Nautical Almanac. As some doubts appear to be entertained as to the exact brilliancy of the Comet, I may state that when I first observed it on Jan. 19, it was certainly as bright as Schäberle's Comet when I found it with the telescope on $188 \mathrm{I}$ Sept. I 7 , and this Comet was seen hy Dr. Gould with the unassisted eye up to Sept. I 4. See Astr. Nachr. No. 2409 . I have no doult that had the Comet been projected on a dark sky about the time of its perihelion passage, it would have been a conspicuous object to the unassisted eye. In conclusion I may add that it cannot possibly be identical with the Comet reported from New Norfolk in Tasmania.

Windsor, N.S. Wales, Private Observatory, I 884 May $3 \mathrm{I}$.

Fohn Teblutt.

Zusatz. Die an die in A. N. $25_{3} 3$ berechneten Positionen anzubringenden Correctionen sind nach Dr. Kreltz:

$$
\begin{aligned}
& 1884 \text { Jan. I } 9.00 \quad \text { 0." } \\
& 19+0.07-0.5 \\
& 2 \mathrm{I}+0.15 \quad-1.1 \\
& 2 \mathrm{I}+\mathrm{O} . \mathrm{I} 7 \mathrm{I} \cdot 3
\end{aligned}
$$$$
\begin{array}{rrr}
1884 \text { Jan. } 22 & +0.10 & -0.8 \\
22 & +0.12 & -0.9 \\
23 & +0.06 & -0.5 \\
23 & -0.08 & -0.6
\end{array}
$$

Zar Berechnung der Bahn wird man übrigens nur die von Herrn Tebbutt selbst A. N. 2585 angegebenen Daten benutzen, da dieselben gegen die vorläufige Mittheilung im 》Observatory * wesentlich verbesserte $A$ NP(). enthalten.

Kr.

\section{Elemente und Ephemeride des Cometen 1884 Barnard. Nach Circular 5 I der Wiener Akademie.]}

\section{E) lemente}

\begin{tabular}{|c|c|c|c|}
\hline 1884 & Mittl. Zeit & $\alpha$ app. & $\delta$ app. \\
\hline Juli 16 & I $5^{\mathrm{h}} 2 \mathrm{I}^{\mathrm{m}} \mathrm{O}$ Greenw. & $237^{\circ} 40^{\prime} \quad 0^{\prime \prime}$ & $-37^{\circ} 9^{\prime} 5^{\prime \prime \prime}$ \\
\hline 23 & 928.2 Algier & $240 \quad 5^{\circ} 3^{8}$ & $\begin{array}{lll}-37 & 14 & 1\end{array}$ \\
\hline 29 & 850.8 & $244 \quad 26$ & -37 I 539 \\
\hline
\end{tabular}

des von Barnard am 16. Tuli i 884 entdeckten Cometen, berechnet von Prof. 1)r. E. Weiss.

Die Elemente sind aus folgenden Beobachtungen berechnet:

$$
\left.\begin{array}{rl}
T & =1884 \text { Aug. I } 7.548 \mathrm{I} \\
x & =301^{\circ} 57^{\prime} 4^{\prime \prime} \\
\delta & =357455^{\mathrm{I}} \\
i & =7 \quad 23^{\mathrm{r}}
\end{array}\right\} \text { Mittl. Aequ. } 1884.0
$$

\begin{tabular}{|c|c|c|c|c|c|c|}
\hline I 884 & & $a$ & $\delta$ & $\log A$ & $\log r$ & $\mathrm{H}$ \\
\hline Aug. 10 & $16^{\mathrm{h}}$ & $54^{m} 35^{s}$ & $-3^{6^{\circ}} 50^{\prime} .2$ & 9.7944 & 0.1491 & \\
\hline 14 & 17 & 844 & $-3^{6} 3^{\text {I. } 8}$ & 9.7975 & 0.1482 & I. ro \\
\hline 18 & & $234 \mathrm{I}$ & $36 \quad 6.0$ & 9.8020 & 0.1480 & \\
\hline 22 & 17 & 39 I 5 & $-353^{2.9}$ & 9.8080 & 0.1485 & I.05 \\
\hline 26 & 17 & 55 I 6 & $-34 \quad 5^{2.2}$ & $9.8 \times 53$ & $0.149^{8}$ & \\
\hline 30 & 18 & I 32 & $-34 \quad 4.2$ & $9.824 \mathrm{I}$ & 0.1518 & 0.96 \\
\hline Sept. 3 & 18 & 2753 & -33 & 9.8344 & o. 1545 & \\
\hline 7 & I 8 & $44 \quad 7$ & $-3^{2}$ & 9.8461 & 0.1579 & 0.84 \\
\hline
\end{tabular}

Darstellung des mittleren Ortes im Sinne Beob. - Rechn.:

$$
\begin{aligned}
\mathrm{d} \lambda \cos \beta & =-\mathbf{I}^{\prime} \mathrm{II}^{\prime \prime} \\
\mathrm{d} \beta & =+\mathrm{I} \text { I } 2
\end{aligned}
$$

Dieser Fehler lässt sich durch eine Variation ron $\mathrm{M}$ nicht weiter herabmindern, düfte also darauf hinweisen, dass die Bahn von einer Parabel erheblich abweicht.

Nach diesen Elementen hat Herr Dr. K. Zelbr folgende Ephemeride berechnet, welche für $12^{\mathrm{h}}$ mittl. Berl. Zeit gilt:

Der Comet wird also wohl Mitte September mindestens auf den sudlicheren Observatorien Furopas beobachtet werden können. 